\title{
ХАРАКТЕРИСТИКА КЛІНІЧНОГО ПЕРЕБІГУ ГАСТРОЕЗОФАГЕАЛЬНОЇ РЕФЛЮКСНОЇ ХВОРОБИ ТА ОЦІНКА ПСИХОСОМАТИЧНОГО СТАНУ ДАНИХ ПАЦІЕНТІВ
}

\author{
ОК. О. Дебрецені, І. В. Чопей, К. І. Чубірко \\ ДВНЗ «Ужгородський національний університет»
}

РЕЗЮМЕ. Мета - оцінка впливу психосоматичного стану на клінічний перебіг і якість життя хворих на ГЕРХ.

Матеріал і методи. У групу обстеження було включено 80 пацієнтів із ГЕРХ. Клінічне обстеження хворих включало традиційну оцінку скарг, анамнезу захворювання і життя, даних об' єктивного обстеження. Психологічна частина обстеження складалася з індивідуальної бесіди з пацієнтом і психодіагностичних тестів.

Результати. Проведено аналіз основних показників, що відображають дані про захворювання на ГЕРХ, тривалість його перебігу і частоту виникнення. Проведено оцінку та аналіз основних клінічних та психосоматичних проявів захворювання.

Висновки. Неерозивна ГЕРХ знижує якість життя хворих за всіма шкалами фізичного і психологічного здоров'я.

КЛючОВІ СлОВА: гастроезофагеальна рефлюксна хвороба; клінічний перебіг; психосоматичний стан; якість життя.

Вступ. Надзвичайна поширеність гастроезофагеальної рефлюксної хвороби $[1,2]$ у світі обумовлює те, що в останні роки захворювання займає одне з чільних місць у структурі гастроентерологічної захворюваності. Щотижня симптоми захворювання виявляються у 20 \% дорослого населення [3], що закономірно призводить до значного зниження якості життя при цій хворобі $[4,5]$. При цьому поширена переважно неерозивна форма захворювання (HEPX) [6].

На сьогодні вже добре відомо, що функціонування системи органів травлення тісно пов' язане зі станом психічної сфери людини. Більшість паці$\epsilon$ нтів із захворюваннями ШКТ, які звертаються до лікарів, мають зміни в психологічному статусі. Психосоматичні захворювання надзвичайно поширені, особливо у високорозвинених країнах, причому в зв' язку з прогресуванням стресогенності суспільства зберігається стійка тенденція до їх зростання [7]. Важливу роль у розвитку ГЕРХ, особливо неерозивної форми захворювання, має психосоматична складова, що істотно впливає на клінічний перебіг даної патології та якість життя хворих, адже ті чи інші відхилення в психічній сфері реєструються практично у 55-95 \% пацієнтів [8].

На сьогодні при діагностиці та призначенні лікування ГЕРХ практично відсутні облік і трактування психосоматичних характеристик. Тому психофізіологічні механізми, що розглядаються через призму психосоматичної складової, у осіб, які хворіють на ГЕРХ, потребують більш уважного вивчення [9-11]. Необхідно уточнити характер змін психологічного стану у хворих із ГЕРХ та їх динаміку, пов'язану з особливостями клінічного перебігу захворювання. Питання щодо частоти порушень психологічного статусу у хворих на ГЕРХ досліджені мало, тому вивчення їх взаємозв' язку з клініч- ною картиною цього захворювання, а також їх можливого впливу на якість життя пацієнтів, є досить актуальним.

Мета - оцінити вплив психосоматичного стану на клінічний перебіг і якість життя хворих із неерозивною формою ГЕРХ.

Завдання дослідження.

1. Дати характеристику основних клінічних проявів у пацієнтів з неерозивною і ерозивною формами ГЕРХ.

2. Оцінити особливості психосоматичних розладів у хворих з НЕРХ у порівнянні з хворими на ерозивну форму.

3. Провести аналіз показників якості життя пацієнтів даних груп.

Матеріал і методи дослідження. Було обстежено 80 пацієнтів із ГЕРХ. Співвідношення чоловіків і жінок склало 1,5:1 (48 і 32 особи відповідно).

До першої групи увійшов 51 хворий із неерозивною рефлюксною хворобою; до другої групи 29 хворих із ерозивною рефлюксною хворобою (EPX). Термін перебігу захворювання у пацієнтів в даній вибірці становив у середньому $(6,6 \pm 3,4)$ років, в межах від 1 до 10 років.

методи клінічного дослідження. Клінічне обстеження хворих включало в себе традиційну оцінку скарг, анамнезу захворювання і життя, даних об' єктивного обстеження. 3 метою більш ретельного обстеження кожен пацієнт проходив спеціальне анкетне скринінгове дослідження.

Mетоди інструментального дослідження. Ендоскопічне дослідження слизової оболонки стравоходу проводили у всіх обстежених пацієнтів із ГЕРХ. При проведенні цього дослідження оцінювали макроскопічні зміни у слизовій оболонці, характер і ступінь їх вираження. Гістологічне дослідження біоптатів слизової оболонки стравоходу 
Огляди літератури, оригінальні дослідження, погляд на проблему, випадок з практики, короткі повідомлення проводили з метою виключення стравоходу Барретта і злоякісних новоутворень. 3 метою виключення супутньої патології органів черевної порожнини всім було проведено ультразвукове дослідження органів черевної порожнини.

Memoдu психологічного дослідження. Психологічна частина обстеження складалася з індивідуальної бесіди з пацієнтом (виявлення первинності емоційно-стресової причини дебюту або загострення хвороби) і психодіагностичних тестів, таких як Міннесотський багатофакторний особистісний опитувальник (ММРI) у модифікації СБОО (скорочений багатофакторний опитувальник особистості) та Шкала тривожності Спілбергера-Ханіна. Дослідження якості життя (ЯЖ) у хворих із

ГЕРХ проводили за допомогою опитувальника MOS SF-36 (Medical Outcomes Study-Short Form).

Результати й обговорення. 3 метою оцінки особливостей клінічних проявів ГЕРХ було проведено аналіз основних показників, що відображають дані про захворювання, тривалість його перебігу і частоту виникнення в залежності від віку та характеру харчування хворих.

За допомогою кореляційного аналізу були виділені групи чинників (етіологічні, пов' язані зі способом життя та особливостями харчування, патогенетичні й клінічні прояви), достовірно $(p<0,05)$ пов'язані зі значеннями основних досліджених характеристик клінічного перебігу захворювання при різних формах ГЕРХ (табл. 1).

Таблиця 1. Характеристика частоти клінічних проявів езофагеальних симптомів, n (\%)

\begin{tabular}{|c|c|c|}
\hline \multirow{2}{*}{ Клінічна ознака } & \multicolumn{2}{|c|}{ Форми ГЕРХ } \\
\cline { 2 - 3 } & HEPX & $22(75,86)$ \\
\hline Печія, в тому числі & $20(39,21)^{*}$ & $20(68,96)$ \\
\hline після переїдання & $8(15,68)$ & $2(65,51)$ \\
\hline після погрішності в дієті & $9(17,64)$ & $4(13,79)$ \\
\hline після куріння & $2(3,92)$ & $4(13,79)$ \\
\hline після алкоголю & $3(5,88)$ & $4(13,79)$ \\
\hline після фізичного навантаження & $3(5,88)$ & $12(41,37)$ \\
\hline при нахилі тулуба & $2(3,92)$ & $9(10,34)$ \\
\hline Відрижка: кислим & $39(76,47)^{*}$ & $2(6,89)$ \\
\hline їжею & $5(9,80)$ & $1(3,44)$ \\
\hline повітрям & $20(39,21)$ & $2(6,89)$ \\
\hline гірким & $2(3,92)$ & $1(3,44)$ \\
\hline Відчуття грудки за грудиною & $12(23,52 *$ & \\
\hline Дисфагія & $4(7,84)$ & \\
\hline Одинофагія & $5(9,80)$ & \\
\hline
\end{tabular}

Примітка. *Відмінності між групами I і II з p<0,05.

Аналіз даних свідчив про те, що найчастіше причиною розвитку ГЕРХ була наявність похибок у дієті, таких як споживання жирної, смаженої, гострої їжі, міцного чаю і кави, газованих напоїв.

Другим за значимістю фактором було ожиріння, до того ж, була виявлена пряма залежність між збільшенням індексу маси тіла і ступенем вираженості тяжкості захворювання. Зі шкідливих звичок заслуговувало на увагу вживання алкоголю, який викликав розвиток езофагіту в 16-18 \% випадків.

Найчастішими з диспепсичних проявів при всіх формах ГЕРХ були печія і відрижка. Печія зустрічалася в 39,21 \% випадків при НЕРХ і в 75,86 \% випадків при ЕРХ. Найчастіше пацієнти вважали причиною виникнення печії переїдання і погрішності в дієті, з частотою 1-2 рази на тиждень ( $<<0,05)$.

Відрижка виникала в основному після переїдання або вживання газованих напоїв. Відрижка кислим при НЕРХ зустрічалася в 1,5 раза частіше, ніж при EPX (р<0,05). Відрижка гірким, їжею та повітрям виявлялася однаково часто при обох форMax ГЕРХ.

Клінічна симптоматика при різних формах ГЕРХ так само супроводжувалася проявами астено-вегетативного синдрому різного ступеня вираженості. Найчастіше відзначалися дратівливість і порушення сну. При цьому дратівливість відзначалася в половині випадків, практично рівномірно в обох групах. Порушення сну і пригнічений настрій частіше траплялися у пацієнтів із HEPX - більш ніж у 3 рази, порівняно з хворими, у яких були виявлені ендоскопічні ознаки ерозивного езофагіту.

При вивченні психосоматичних проявів було виявлено, що пацієнтам із ГЕРХ притаманні такі типи ставлення до хвороби: тривожний, іпохондричний, обсесивно-фобічний і неврастенічний, 
Огляди літератури, оригінальні дослідження, погляд на проблему, випадок з практики, короткі повідомлення що належать до типів реагування переважно з інтрапсихічною спрямованістю.

Емоційно-афективний аспект відношення у хворих із цими типами реагування клінічно проявлявся в реакціях за типом безперервного занепокоєння щодо несприятливого перебігу хвороби, зосередження на суб'єктивних хворобливих та інших неприємних відчуттях, "дратівливої слабкості», пригніченому стані. В основному ці прояви траплялися у хворих із неерозивною ГЕРХ (у 75 \% випадків), на відміну від пацієнтів із ерозивним езофагітом (у 34 \% випадків).

У хворих з усіма формами захворювання в основному переважали іпохондричний, неврастенічний і тривожний типи ставлення до хвороби. Іпохондричний тип проявлявся в зосередженні хворих на неприємних для них відчуттях, прагненні постійно розповідати про них оточуючим. У хворих із тривожним типом ставлення до хвороби було відзначено занепокоєння і недовірливість щодо несприятливого перебігу хвороби, можливих ускладнень, неефективності і навіть небезпеки лікування. Вони були схильні до пошуку нових способів лікування, додаткової інформації про хворобу та можливі ускладнення. Цікаво також зазначити, що при тривожному типі об'єктивні дані про хворобу (результати аналізів, інструментальних досліджень, висновки фахівців) цікавили пацієнтів більше, ніж власні відчуття.

У групі хворих з ерозивною формою захворювання переважали гармонійний (твереза оцінка свого стану) і неврастенічний типи ставлення до хвороби (спалахи роздратування, особливо при болях, при неприємних відчуттях, при невдачах лікування, невміння і небажання терпіти больові відчуття, нетерплячість в обстеженні і лікуванні, нездатність терпляче чекати полегшення).

Обсесивно-фобічний тип відношення при неерозивних езофагітах характеризувався вираженою тривожністю, вразливістю щодо побоювань не реальних, а малоймовірних ускладнень хвороби, невдач лікування, а також можливих невдач у житті та роботі в зв'язку з хворобою. Тривожний тип ставлення до хвороби проявлявся нападами стурбованості й підозріливості щодо несприятливого перебігу хвороби та можливих ускладнень.

Показники особистісної тривожності у хворих 1 групи свідчили про високий рівень тривожності, у хворих 2 групи - про помірний. При цьому у хворих із неерозивною формою ГЕРХ показники особистісної тривожності склали в середньому 54 ба-

ли, а в пацієнтів із ерозивним езофагітом - 42 бали. Реактивна тривожність у хворих із ГЕРХ була помірною і при відсутності ерозивного езофагіту становила 41 бал, а при його наявності - 31 бал.

Отже, отримані дані свідчать про те, що при всіх формах ГЕРХ наявна виражена сукупність психологічних розладів негативного характеру. Найбільш виражений комплекс психологічних розладів виявлено у хворих із неерозивною формою ГЕРХ. При інших формах захворювання психологічні зміни мали менш виражений характер.

При дослідженні якості життя найвищі показники були виявлені за шкалами фізичного, соціального функціонування та психологічного здоров'я. Найнижчі показники отримані за шкалами рольового фізичного та рольового емоційного функціонування.

Найвищі показники за рівнем якості життя (ЯЖ), залежно від форми захворювання, були виявлені у хворих із ерозивною рефлюксною хворобою, а мінімальні - у пацієнтів із неерозивною формою ГЕРХ. Досить низькі показники ЯЖ, що не мали істотних відмінностей залежно від ступеня захворювання, відзначалися за шкалами болю, загального здоров'я, життєздатності та психологічного здоров'я.

Висновки. Диференційними клінічними характеристиками пацієнтів із неерозивною ГЕРХ $\epsilon$ відрижка кислим $(76,47)$ і відчуття грудки за грудниною $(23,52)$, тоді як основним проявом у пацієнтів із ерозивною формою захворювання $є$ печія $(75,86)$.

У хворих із неерозивною ГЕРХ у 87 \% випадків виявляють зміни психологічного статусу негативного характеру. У хворих із неерозивною ГЕРХ частота виявлення депресії і тривожності була більш ніж удвічі вищою, ніж у хворих із ерозивною ГЕРХ. Неерозивна ГЕРХ значно знижує якість життя хворих за всіма шкалами фізичного і психологічного здоров'я, з максимально низькими показниками фізичного компонента, зі збереженням, проте, рольового фізичного функціонування. У хворих із неерозивною ГЕРХ переважно страждають рольові компоненти якості життя, тоді як у хворих із ерозивною ГЕРХ - життєздатність і біль.

3 метою оптимізації та підвищення якості діагностики та лікування ГЕРХ, поряд із традиційними методами обстеження хворих, доцільно проводити аналіз їх психологічного стану із застосуванням методів психологічного тестування та оцінки якості життя пацієнтів. 
Огляди літератури, оригінальні дослідження, погляд на проблему, випадок з практики, короткі повідомлення ЛІТЕРАТУРА

1. Rubenstein $\mathrm{H}$. Epidemiology of gastroesophageal reflux disease / H. Rubenstein, J. W. Chen / Gastroenterol. Clin. North. Am. - 2014. - Vol. 43. - P. 1-14.

2. Бабак О. Я. Гастроэзофагеальная рефлюксная болезнь. От теории к практике / О. Я. Бабак // Сучасна гастроентерологія. - 2014. - № 4. - С. 38-44.

3. Richter J. E. Presentation and epidemiology of gastroesophageal reflux disease / J. E. Richter, J. H. Rubenstein / Gastroenterology. - 2018. - Vol. 154 (2). - P. 267-276.

4. Anxiety and depression reduce QoL in GERD patients / X. J. Yang, H. M. Jiang, X. H. Hou, J. Song // World J. Gastroenterol. - 2015. - Vol. 21. - P. 4302-4309.

5. Чернобровий В. М. Гастроезофагеальна рефлюксна хвороба: функціональна діагностика, вибір інгібіторів протонної помпи та оцінка ефективності їх кислотосупресивної дії / В. М. Чернобровий, С. Г. Мелащенко, О. О. Ксенчин // Сучасна гастроентерологія. - 2015. № 3 (83). - C. 50-58.

6. Maradey-Romero C. Nonmedical therapeutic strategies for nonerosive reflux disease / C. Maradey-Romero, H. Kale, R. Fass // J. Clin. Gastroenterol. - 2014. Vol. 48. - P. 584-589.

\section{REFERENCES}

1. Rubenstein, H., \& Chen, J.W. (2014). Epidemiology of gastroesophageal reflux disease. Gastroenterol. Clin. North. Am., 43, 1-14.

2. Babak, O.Ya. (2014). Gastroezofagealnaya reflyuksnaya bolezn. Ot teoryy k praktyke [Gastroesophageal reflux disease. From theory to practice]. Suchasna hastroenterolohia - Modern Gastroenterology, 4, 38-44 [in Russian].

3. Richter, J.E., \& Rubenstein, J.H. (2018). Presentation and epidemiology of gastroesophageal reflux disease. Gastroenterology., 154 (2), 267-276.

4. Yang, X.J., Jiang, H.M., Hou, X.H., \& Song, J. (2015). Anxiety and depression reduce QoL in GERD patients. World J. Gastroenterol., 21, 4302-4309.

5. Chernobrovyj, V.M., Melashhenko, S.G., \& Ksenchyn, O.O. (2015). Hastroezofahealna refliuksna khvoroba: funkcionalna diahnostyka, vybir inhibitoriv protonnoi pompy ta otsinka efektyvnosti ikh kyslotosupresyvnoi dii [Gastroesophageal reflux disease: functional diagnosis, selection of proton pump inhibitors and evaluation of the effectiveness of their acid-suppressive action]. Suchasna hastroenterolohia - Modern Gastroenterology, 3 (83), 50-58 [in Ukrainian].

6. Maradey-Romero, C. (2014). Nonmedical therapeutic strategies for nonerosive reflux disease. J. Clin. Gastroenterol., 48, 584-589.
7. Demographic, clinical, and psychological characteristics of the heartburn groups classified using the Rome III criteria and factors associated with the responsiveness to proton pump inhibitors in the gastroesophageal reflux disease group / K. J. Lee, H. C. Kwon, J. Y. Cheong, S. W. Cho / Digestion. - 2009. - Vol. 79 (3). - P. 131-136.

8. Choi J. M. Association between anxiety and depression and gastroesophageal reflux disease: Results from a large cross-sectional study / J. M. Choi, J. I. Yang, S. J. Kang / J. Neurogastroenterol. Motil. - 2018. - Vol. 24 (4). P. 593-602.

9. Zhang L. Health-related quality of life in gastroesophageal reflux patients with noncardiac chest pain: Emphasis on the role of psychological distress / L. Zhang, L. Tu, J. Chen / World J. Gastroenterol. - 2017. - Vol. 23 (1). P. 127-134.

10. Острогляд А. В. Гастроезофагеальна рефлюксна хвороба / А. В. Острогляд, А. С. Свінціцький, В. І. Вдовиченко. - Л., 2011. - 266 с.

11. Психологічна дезадаптація пацієнтів з ГЕРХ: огляд та власні дослідження / Л. М. Мосійчук, Л. В. Демешкіна, І. В. Кушніренко, І. Ю. Зав' ялова // Гастроентерологія. - 2014. - № 4. - С. 23-29.

7. Lee, K.J., Kwon, H.C., \& Cheong, J.Y. (2009). Demographic, clinical, and psychological characteristics of the heartburn groups classified using the Rome III criteria and factors associated with the responsiveness to proton pump inhibitors in the gastroesophageal reflux disease group. Digestion., 79, 131-136.

8. Choi, J.M., Yang, J.I., \& Kang, S.J. (2018). Association between anxiety and depression and gastroesophageal reflux disease: Results from a large cross-sectional study. J. Neurogastroenterol. Motil., 24 (4), 593-602.

9. Zhang, L., Tu, L., \& Chen, J. (2017). Health-related quality of life in gastroesophageal reflux patients with noncardiac chest pain: Emphasis on the role of psychological distress. World J. Gastroenterol., 23 (1), 127-134.

10. Ostrohliad, A.V., Svintsitskyi, A.S, \& Vdovychenko, V.I. (2011). Hastroezofahealna refliuksna khvoroba [Gastroesophageal reflux disease]. Lviv [in Ukrainian].

11. Mosiichuk, L.M., Demeshkina, L.V., Kushnirenko, I.V., \& Zavialova, I.Yu. (2014). Psykholohichna dezadaptatsiia patsiientiv z HERKh: ohliad ta vlasni doslidzhennia [Psychological maladaptation of patients with GERD: review and own research]. Hastroenterolohia - Gastroenterology, 4, 23-29 [in Ukrainian]. 
Огляди літератури, оригінальні дослідження, погляд на проблему, випадок з практики, короткі повідомлення

\title{
ХАРАКТЕРИСТИКА КЛИНИЧЕСКОГО ТЕЧЕНИЯ ГАСТРОЭЗОФАГЕАЛЬНОЙ РЕФЛЮКСНОЙ БОЛЕЗНИ И ОЦЕНКА ПСИХОСОМАТИЧЕСКОГО СОСТОЯНИЯ ПАЦИЕНТОВ
}

\author{
ФК. А. Дебрецени, И. В. Чопей, К. И. Чубирко
}

ГВУз «Ужгородский национальный университет»

РЕЗЮМЕ. Цель - оценка влияния психосоматического состояния на клиническое течение и качество жизни больных ГЭРБ.

Материал и методы. В состав обследуемых было включено 80 пациентов с ГЭРБ. Клиническое обследование включало в себя традиционную оценку жалоб, анамнеза заболевания и жизни, данных объективного обследования. Психологическая часть обследования состояла из индивидуальных бесед с пациентами и психодиагностических тестов.

Результаты. Проведен анализ основных показателей, которые отражают данные о ГЭРБ, длительность ее течения и частоту возникновения. Проведена оценка и анализ основных клинических и психосоматических проявлений заболевания.

Выводы. Неэрозивная ГЭРБ снижает качество жизни пациентов по всем шкалам физического и психологического здоровья.

КЛЮЧЕВЫЕ СЛОВА: гастроэзофагеальная рефлюксная болезнь; клиническое течение; психосоматическое состояние; качество жизни.

\section{CHARACTERISTICS OF THE CLINICAL COURSE OF GASTROESOPHAGEAL REFLUX DISEASE AND ASSESSMENT OF THE PSYCHOSOMATIC STATE OF THESE PATIENTS}

@K. O. Debretseni, I. V. Chopey, K. I. Chubirko Uzhhorod National University

SUMMARY. The aim - to assess the impact of psychosomatic conditions on the clinical course and quality of life of patients with GERD.

Material and Methods. The examined population included 80 patients with GERD. Clinical examination of patients included the traditional assessment of complaints, medical and life history, objective examination data. The psychological part of the examination consisted of an individual conversation with the patient and psychodiagnostic tests.

Results. The main indicators that reflect the data on GERD, its duration and frequency of occurrence had been analyzed. An assessment and analysis of the main clinical and psychosomatic manifestations of the disease had been completed.

Conclusions. Non-erosive GERD significantly reduces the quality of life of patients in all scales of physical and psychological health.

KEY WORDS: gastroesophageal reflux disease; clinical course; psychosomatic condition; quality of life.

Отримано 10.02.2021 